University of Tennessee College of Law

Legal Scholarship Repository: A Service of the Joel A. Katz Law Library

UTK Law Faculty Publications

3-2011

Responding to Welfare Privatization: New Tools for a New Age

Wendy A. Bach

Follow this and additional works at: https://ir.law.utk.edu/utklaw_facpubs

Part of the Law Commons 


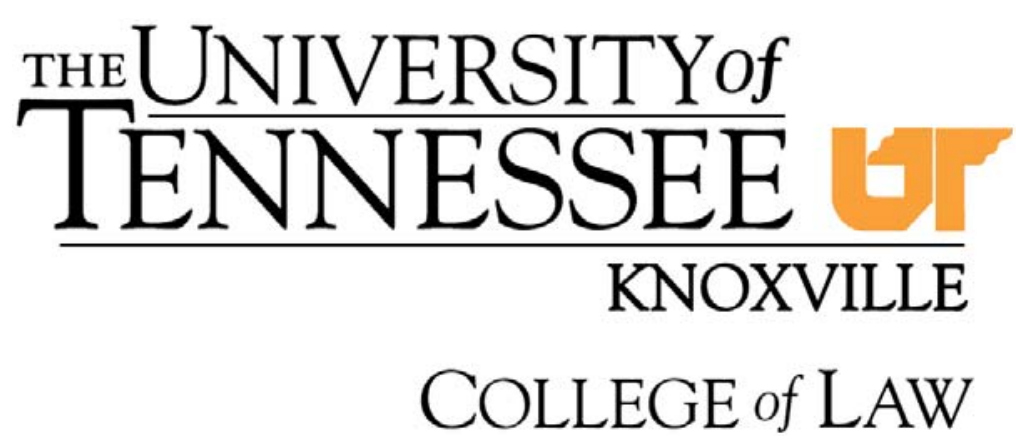

Legal Studies Research Paper Series

Research Paper \#147

June 2011

\section{Responding to Welfare Privatization: New Tools for a New Age}

Wendy A. Bach 


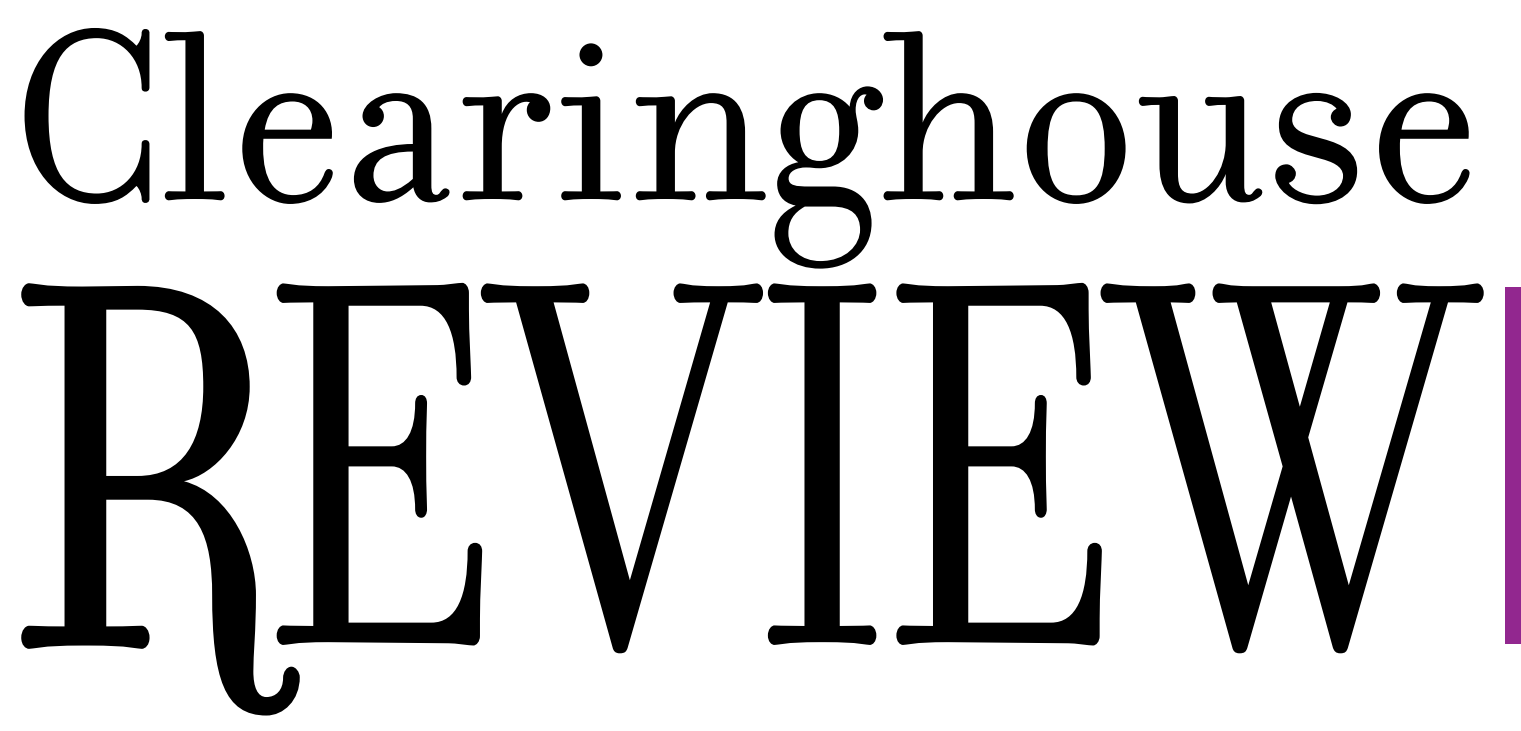

March-April 2011

Volume 44, Numbers 11-12

Journal of

Poverty Law

and Policy

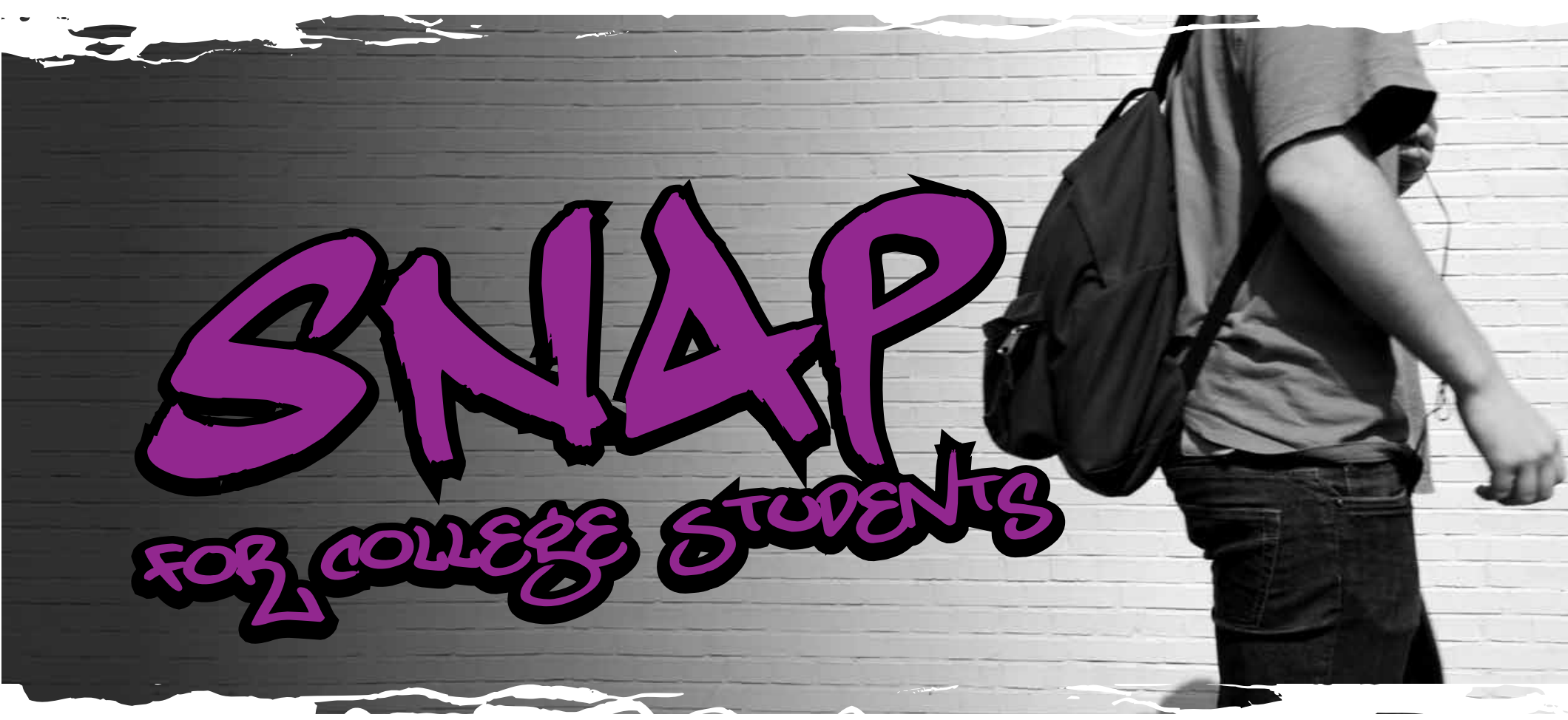

Reasonable Accommodations in Assisted Living

Negotiated Rulemaking

Medical-Legal Partnerships

Welfare Privatization

Child Welfare Financing Reform

LGBT Elders' Economic Security and Health Care 


\section{Responding to Welfare Privatization:

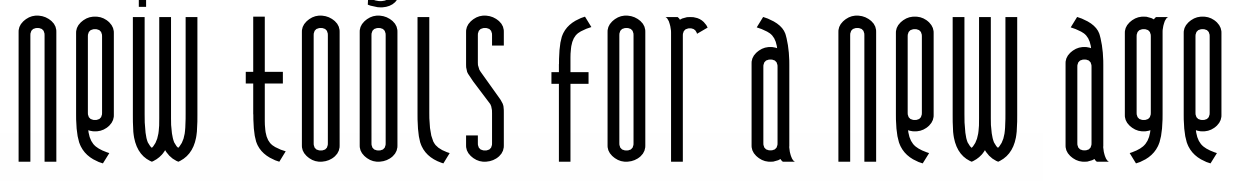

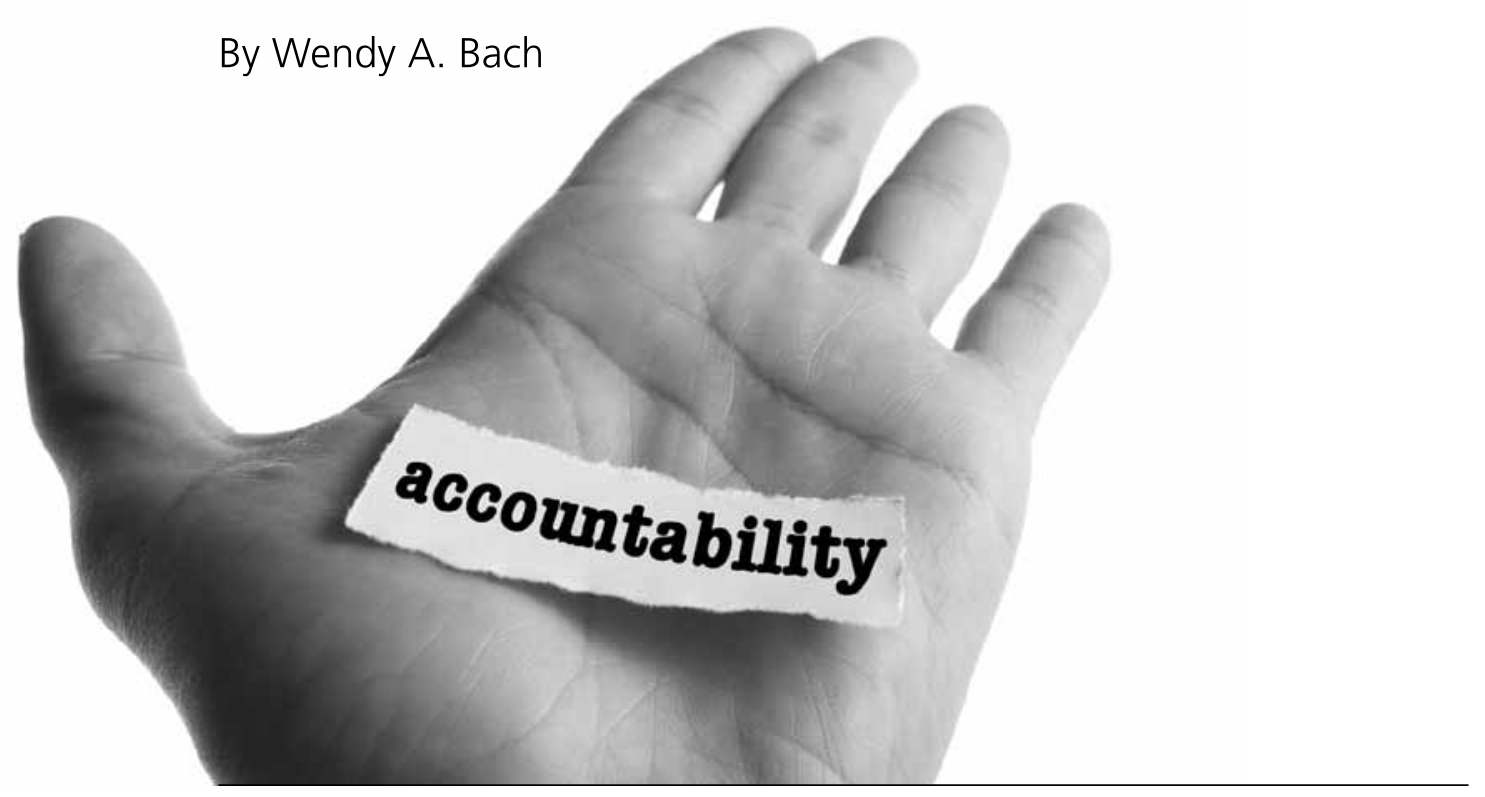

[Editor's Note: Wendy A. Bach adapted this article from her much longer and more extensively notated Welfare Reform, Privatization and Power: Reconfiguring Administrative Law from the Ground Up, 74 BRooklyn LaW ReVIEW 275 (2009).]

Wendy A. Bach Associate Professor

University of Tennessee College of Law 1505 W. Cumberland Ave. Knoxville, TN 37917

865.974 .2331

wbach@utk.edu
$\mathbf{P}$ rivatization of public assistance in the United States accelerated noticeably in the last fourteen years. The 1996 welfare reform law, the Personal Responsibility and Work Opportunity Reconciliation Act, joined a rising tide of initiatives to "reinvent government" by using private-sector tools and entities to free government from the constraints of perceived excessive bureaucracy and constrictive civil service rules. ${ }^{1}$ In the welfare-to-work area, privatization played a key and quite disturbing role in a very effective campaign to reduce the welfare rolls drastically. Moreover, contracting for services with private entities, both for-profit and nonprofit, substantially diminished the effectiveness of traditional legal advocacy strategies. Advocacy tools, be they rights to due process, sunshine laws, or public rulemaking requirements, were designed with fully government-run systems in mind. In the face of privatization, these tools are less effective.

In this context accountability can encompass two basic concepts: accountability to individuals for fair and consistent application of rules and-a more public conception of accountability - the ability of poor communities and their advocates to affect welfare policy. Here, picking up the conversation about the impact of privatization that took place in Clearinghouse Review in 2002, I focus on the latter. ${ }^{2}$

In considering how privatized structures might be made more accountable, I describe a case study from New York City of the devastatingly effective way in which a government agency, with little or no oversight, can use privatization to impose harsh poli-

1Personal Responsibility and Work Opportunity Reconciliation Act, Pub. L. 104-193, 110 Stat. 2105 (1996).

${ }^{2}$ See Clearinghouse Review's special issue, The Implications of Privatization on Low-Income People, 35 Clearinghouse Review (Jan.-Feb. 2002). 
cies. When framed within broader shifts in governing mechanisms, the case study also sheds light on how the advocacy community might respond. Ultimately I suggest that, besides continuing to insist that government conform to preexisting rights norms and slow or stop privatization when it creates harm, poverty lawyers and poor communities must work together to design and use new accountability mechanisms that engage with privatized structures directly.

\section{Case Study: Welfare Reform and Privatization in New York City}

The story of welfare privatization, nationally and in its implementation in New York City, tells a disturbing story of how the change in governing structures, from public to private, led to the imposition of profoundly punitive policies with little to no oversight. At the same time the advocacy communities' struggle to respond teaches important lessons for moving forward.

\section{A. The National Context: A Move Toward Privatization}

The move to welfare privatization arose in large part from two significant shifts in federal law. First, a provision of the Personal Responsibility and Work Opportunity Reconciliation Act allowed states and localities to contract out eligibility determinations for Temporary Assistance for Needy Families (TANF), creating a new and potentially tremendously lucrative market for the for-profit sector. ${ }^{3}$ Second, the statute devolved authority for setting welfare policy from the federal government to states and localities. The Act envisioned widespread state and local experimentation and, in many ways, paralleled the incentive contracts that would emerge in the welfareto-work arena. States were given a fixed block grant, comparatively few man- dates, and enormous motivation to lower their welfare caseloads by any means they saw fit. The federal government's message to the states was crystal clear: if you cut the welfare rolls, you will be rewarded financially, and, to a far greater degree than was true under the Aid to Families with Dependent Children program, we will not hold you accountable for the means by which you achieve this goal. These twin invitations-to privatize provision of services and to use virtually any means to lower the rolls-created an ideal environment for a growth in the role of private entities.

And grow that role did. The most recent national survey reported that in 2001 forty-nine states and the District of Columbia used contracts with private entities to provide some welfare services. ${ }^{4}$ Spending under these contracts exceeded $\$ 1.5$ billion, which was at least 13 percent of federal TANF and state noncash assistance expenditures. If the use of private entities grew, the use of forprofit entities grew exponentially. Of the $\$ 1.5$ billion, 13 percent went to for-profit entities by 2001.5

\section{B. Welfare Reform and Privatization in New York City}

Welfare reform of the kind envisioned by the 1996 federal law began in earnest in New York City a year earlier. In 1995 Mayor Rudolph Giuliani and Human Resources Commissioner Jason Turner initiated a wide-ranging set of welfare reforms designed, in the words of Commissioner Turner, to create "a crisis in welfare recipients' lives, precipitating such dire prospects as hunger and homelessness." 6

The move to privatization came a few years later. In 1999 the Giuliani administration put out for bid $\$ 500$ million in contracts to provide welfare-to-work

${ }^{3} 42$ U.S.C § 604a(a)(1)(A) (2001).

4See U.S. General Accounting Office, GaO-02-245, Welfare Reform: Interim Report on Potential Ways to Strengthen Federal. Overisht of State and Local Contracting 8 (2002), http://bit.ly/egP8TB.

$5 / d$.

${ }^{6}$ Committee on Social Welfare Law, New York City Bar, Welfare Reform in New York City: The Measure of Success § I.C (Aug. 2001), http://bit.ly/fVxcLO (citing Commissioner Jason Turner, Address at the Nelson A. Rockefeller Institute of Government (Nov. 1998)) [hereinafter Welfare Reform in New York City]. 
services for public assistance recipients. ${ }^{7}$ Privatization of these services proceeded and expanded over the next several years through contracts to conduct employment assessments, serve individuals who alleged physical and mental impairments that interfered with their ability to work, and provide a variety of other services. The contracts were generally performance-based, that is, contractors were paid only when they met performance goals for a particular client.

\section{The Advocacy Community's Response to Welfare Reform}

Central among the advocacy community's strategies were class action lawsuits to stop or slow the implementation of key welfare reform initiatives and a series of lobbying and organizing efforts to blunt the harshest effects of reform. ${ }^{8}$ The litigation slowed implementation of welfare reform and ensured some adherence to both due process and substantive rights. Similarly lobbying preserved some protections that had been assured under Aid to Families with Dependent Children, TANF's predecessor. ${ }^{9}$ Nevertheless, evaluated solely on the basis of whether the rolls plummeted, welfare reform was disturbingly effective. Between 1994 and 2010, the welfare rolls in New York City plummeted an astounding 69.6 percent. $^{10}$ If parallel improvements in the economic circumstances of former welfare recipients had accompanied those roll reductions, advocates could have concurred with the administration that welfare reform was a success-but, as was the case nationwide, such improvements did not occur. ${ }^{11}$ The social safety net was largely dismantled; families remained steeped in deep poverty and ever more vulnerable to the vagaries of the lowwage labor market. ${ }^{12}$

\section{The Advocacy Community's Response to Privatization}

While the traditional forms of advocacy, such as litigation and lobbying, affected privatization only indirectly, other efforts faced the issues arising from privatization more squarely. In 1999 the Giuliani administration sought to let $\$ 500$ million in contracts with private entities to provide welfare-to-work services. ${ }^{13}$ Almost immediately the bidding embroiled the administration in a scandal. City Comptroller Alan Hevesi investigated allegations that the administration violated fair bidding rules by engaging in "wide-ranging discussions ... on its "welfare reform efforts" with officials at Maximus Inc., the eventual recipients of the largest share of the contracts, five months before its first informational meeting with other prospective bidders. ${ }^{14}$ The comptroller engaged in a protracted but ultimately unsuccessful effort to stop the letting of a contract to Maximus. ${ }^{15}$

\section{${ }^{7}$ See id.}

${ }^{8}$ Among the litigation efforts was Reynolds v. Giuliani, 35 F. Supp. 2 d 331 (S.D.N.Y. 1999), which challenged the conversion of welfare centers from Income Support Centers to "Job Centers" on the ground that the agency was "preventing people from applying for Medicaid, food stamps, cash assistance, and emergency assistance in violation of federal and state statutory and constitutional law" (id. § II.A.1). For an in-depth look at the litigation efforts of the advocacy community from 1996 forward, see National Center for Law and Economic Justice, Case Developments (1996-2004) (n.d.), http:// bit.ly/dEFWg5.

9See, e.g., Stephen Loffredo, Poverty Law and Community Activism: Notes from a Law School Clinic, 150 UNIVERSITY OF Pennsylvania Law Review 173, 193-96 (2001) (discussing the lobbying campaign spearheaded by the Welfare Rights Initiative, a community-based organizing group, and supported by a City University of New York Law School clinic to expand access to education and training through amendments to state legislation and characterizing those changes as reclaiming ground lost as a result of welfare reform).

${ }^{10}$ New York City Human Resources Administration, Cash Assistance Recipients in NYC 1955-2010 (2011), http:scr.bi/hKOtdu

${ }^{11}$ Welfare Reform in New York City, supra note 6 (discussing rise in hunger and homelessness).

${ }^{12}$ See, e.g., id § II.A.1.

${ }^{13} / d$.

${ }^{14}$ Nina Bernstein, Company Had Head Start Preparing Bid in Welfare-to-Work Program, New York Times, March 10, 2000, at B6.

${ }^{15}$ See Welfare Reform in New York City, supra note 6. 
In 2004 and 2005 a grassroots organization in New York City began to research the effectiveness of welfare-to-work contracts. The organization, Community Voices Heard, describes itself as comprising "low-income people, predominantly women ... on welfare, working to build power in New York City ... to improve the lives of our families and communities." ${ }^{16}$ The report that it published is one of the few pieces of qualitative research documenting the difficulties welfare recipients experience in privatized service environments. ${ }^{17}$ The report contains essential data on how privatization harms poor communities, augments and legitimates an organizing campaign to improve welfare policy, and offers an effective model of advocacy to address the harms of privatization.

Community Voices Heard studied the effectiveness of New York City's contracts with private vendors for provision of welfare-to-work services. ${ }^{18}$ Taking the city at its word that the program's main goal was to move people from welfare to work, Community Voices Heard's researchers "set out to uncover whether or not currently operating job readiness and job placement programs accomplish their intended goals, what stands in their way, and how they might be improved to better serve the needs of the clients, the providers, and the system at large." ${ }^{19}$ With few exceptions, the researchers found a system that was almost completely failing to meet its stated goals.

The contracts were entirely performancebased, meaning that vendors were paid only when a client reached a particular outcome. The city projected that of the individuals who enrolled in the program, 46 percent would be placed in jobs, 35 percent would retain their jobs for three months, and 25 percent would retain them for six months. The actual outcomes were far less impressive. Of the average of 4,144 people who were referred into the system each month, only 8 percent, or 34,6 , were placed in employment; of those, 43 percent (149 individuals) still had their jobs after three months and 35 percent (121 individuals) had their jobs after six months. The program referred clients to jobs that offered low salaries, little stability, and very little chance of escaping poverty. Of those with Employment Services and Placement vendorreferred jobs, 75 percent earned $\$ 8.00$ per hour or less and 19 percent were referred to part-time positions; many of the fulltime positions were temporary. Of those whose job placements allowed closure of their welfare cases, 29 percent returned to public assistance within six months and 36 percent were unaccounted for.

Given the low placement and retention figures, Community Voices Heard focused large portions of the report on documenting what happened to the 92 percent who were not placed and what led to the low placement outcomes. Sanctions were imposed on a disturbingly high number of individuals for failure to comply with rules. Of those referred to vendors by the agency each month, 76 percent (an average of $3,14,9$ people) fell into this category either because they did not attend the program at the start (3o

${ }^{16}$ Community Voices Heard, Our Mission (n.d.), http://www.cvhaction.org.

${ }^{17}$ Sondra Youdelman \& Paul Getsos, Community Voices Heard, The Revolving Door: Research Findings on nyC's Employment Services and Placement System and Its Effectiveness in Moving People from Welfare to Work 21 (2005), http://bit.ly/ekVPsN [hereinafter ReVolving Door]. But see Frank Munger, Dependency by Law: Poverty, Identity, and Welfare Privatization, 13 Indiana Journal of Global Legal Studies 391 (2006). Relying on extensive focus group interviews with welfare recipients and other actors in the social welfare system in Buffalo, New York, Professor Munger relates a fascinating account of the effects of privatization and other aspects of welfare reform on the self-perception of women receiving welfare (id. at 392).

${ }^{18}$ Revolving Door, supra note 17, at 2. The program studied was New York City's Employment Services and Placement program, which was designed to serve approximately 27,000 clients per year at a cost of approximately $\$ 43$ million (id. at 28). Individuals participated for thirty-five hours per week for a maximum of six months. For the first two weeks of the program, they spent all their time with the private vendor, engaging in assessment, job readiness, and job search activities. Subsequently they spent two full days a week at the vendor's site and three days in a work experience placement at another site. The goal of the program, according to city documents, was to "assist all non-exempt" applicants and participants in achieving self-reliance through paid employment (id. at 27).

${ }^{19} /$ d. at 13 . In order to evaluate program effectiveness, Community Voices Heard analyzed agency documents obtained through Freedom of Information Act requests, performed a random survey of 600 clients, interviewed staff members from all but one of the vendors, and conducted twelve in-depth client interviews (id. at 17-18). 
percent of those referred) or because the agency found failure to comply with one or more of myriad program rules later in the process (46 percent of those referred). This contrast between the 121 people who still had jobs after six months and the more than 3,000 people punished monthly represented, in Community Voices Heard's estimation, an utterly failed system. Despite these clear failures, when the city redesigned and rebid the contracts in 2006, contract incentives were modified only slightly, and the same vendors received new contracts.

These two pieces of data-that the overwhelming majority of recipients ended up sanctioned rather than employed and that contracts were nonetheless re-let to the same vendors on similar termssuggest something quite disturbing. As noted above, welfare reform has been deemed a success in large part because of the radical reductions in caseload. However, those reductions have not been accompanied by advancement of welfare recipients in the labor market. The employment services and placement program, though promoted as one designed to move people into the labor force, appear much more successful at punishment than at placement. Given the agency's apparent endorsement of these outcomes through the re-letting of contracts to the same vendors, one can speculate that the agency endorsed these devastating outcomes.

\section{Privatization Incentives: The Motivating Forces Behind Failure}

CommunityVoices Heard's report not only documented the failures of the welfareto-work system but also identified the systemic problems that led to these outcomes. The report's wide-ranging criticisms noted problems that predicted failure, including the lack of experienced job developers and inadequate curriculum for job skills training. For the purposes of this discussion, however, the most interesting critiques focused on how both the formal contract terms, and the formal and informal contract performance monitoring, failed to create meaningful employment. ${ }^{20}$ The report particularly criticized lack of access to education and training and the contractual disincentives to serving clients whose path to work would be challenging.

State law requires that in many circumstances the agency honor a client's preference for education or training, and 71 percent of clients wanted to attend education or training. ${ }^{21}$ But one in three clients "did not know that education and training might satisfy a portion of their work requirements," and only 18 percent of participants attended such programs. ${ }^{22}$ The report pointed to the structure of the contract payment system as the reason for failing to provide education and training. ${ }^{23}$ Because vendors were paid only for job placement and retention, they focused their efforts on placement as the most likely strategy to improve their rates and thus their payment. Performance incentives led them to "cream"-to select out and serve those who were easier to serve, and avoid serving those with greater needs. The contracts offered no incentive to place people in education and training.

Community Voices Heard reported that vendors were "discouraged from working with clients for the long amount of time often necessary to address barriers and [were] instead encouraged to sanction them." 24 As one vendor reported, " $[\mathrm{t}]$ he incentives are structured in a way that encourages vendors to work with those easiest to place quickly, and leave behind those that need more support and more time for initial placement. Clients realize this and grow wary of a system that is failing to meet their needs." ${ }^{5}$ Ven-

\footnotetext{
${ }^{20} / d$. at $69-71$.

${ }^{21}$ N.Y. Soc. Serv. Law $\S 335$ (McKinney 1997); Revolving Door, supra note 17, at 64.

${ }^{22}$ Revolving Door, supra note 17, at 53.

${ }^{23} / d$. at $69-71$

${ }^{24} / d$. at 8 .

${ }^{25} / d$
} 
dors also consistently reported informal pressure by the agency to punish rather than to serve clients.

The report documents what many have always known about privatization through contracting: despite robust legal rules, contract incentives govern vendor behavior. Moreover, performance is shaped not only by formal contract incentives but also by informal monitoring mechanisms. When the city agency pushed vendors to sanction clients rather than deliver services, this dynamic became clear.

Although Community Voices Heard, through great effort, uncovered and reported these data, the contract terms and contract monitoring structures that led to these outcomes were created with little or no public scrutiny. Thus privatization was an extraordinarily effective mechanism to design and implement a program of highly punitive welfare policies without public input or initial scrutiny. This lack of public input is precisely the problem that I address here.

\section{The Tools We Have}

Traditional administrative law offers a variety of tools designed to ensure that the government, when it formulates policies, is accountable to the public and adheres to fundamental democratic norms. Chief among these structures are freedom of information and sunshine laws that require the government to give notice of administrative rulemaking and an opportunity for the public to comment and that require the government to allow members of the public to sue if an administrative agency acts outside the boundaries of its statutory mandate. Administrative law includes rules governing procurement processes. However, these regulatory schemas offer little to help communities respond to the problems of welfare privatization described above.

As a conceptual matter, freedom of information, sunshine, and notice and comment laws-as well as causes of ac- tion for exceeding statutory authorityare predicated on a traditional concept of administrative law: the administrative agency, created and governed by enabling legislation, in turn creates and implements rules that control the agency's interactions with the public. To check what would otherwise be inappropriate power, the agency is subject to a variety of mechanisms designed to render its conduct more democratic.

Each of these tools presumes that a government agency is the primary actor. If the government is not the actor, whether any of these laws applies is far from clear, leaving in doubt the effectiveness of using litigation to create accountability. Moreover, tools such as these traditionally apply when an administrative agency acts in a quasi-legislative role, raising concerns about the need to check inappropriate exertion of power. Historically, contracting has not been viewed as quasi-legislative, and so these protections generally do not apply when the government is issuing contracts. ${ }^{26}$ As a result, these protections fail to solve the problems posed by welfare privatization.

Another body of public law that provides some possibilities for public participation is that governing public procurement processes. However, this body of law focuses almost exclusively on ensuring that the government receives a fair price and avoids corruption. Given this focus, public procurement rules provide little in the way of public accountability to clients and communities. Although traditional public law might offer less than we might hope in a privatized setting, some emerging governance structures offer more promise.

\section{Trends in Governance}

Several current trends in administrative governance offer potential avenues to enhance accountability. Like privatization, these governance trends raise concerns about both their effectiveness and their ability to ensure basic fairness. Nevertheless, both whether they

${ }^{26}$ See, e.g., 5 U.S.C. § 553(a)(2) (2006) (excluding government contracting from the notice and comment provisions of the Administrative Procedure Act). 
offer some potential to do good and whether there are ways to capitalize on these trends to create better programs for poor communities are worth considering in light of the political popularity and upsurge in use of these trends. Below I describe these trends as well as some of their potential problems and conclude with a proposition that we embrace a more robust and community-focused version of them as a way to deal with the public accountability problems at the heart of welfare contracting.

The last decade has seen-along with increased privatization of government services-the creation both nationally and internationally of governing structures that move away from "command and control" forms of law and regulation and toward collaborative governing regimes that invite local experimentation to meet broadly defined objectives. Over time, lessons can be adopted based on evaluations of a range of these experiments. In theory these new governing structures can lead to better programs because they engage a broader number of actors and can adapt to changing conditions. ${ }^{27}$

Two examples give some texture to these trends. First, and quite close to welfare, is the governing structure of the Workforce Investment Act. ${ }^{28}$ In place of a federal mandate to provide either particular services or clear, individually focused procedural rights, the Act adopts a broad series of goals and a variety of structures to foster community collaboration in creating programs to meet these goals. Enabling legislation mandates the creation of state and local workforce investment boards with broad membership and extensive policymaking authority. Boards are charged with designing programs, evaluating them, and redesign- ing in light of those evaluations. The Act envisions that localities and states will share data to improve program design over time. ${ }^{29}$

Similarly New York City's Center for Economic Opportunity offers a prime example of trends in the governing structure of poverty programs. Rather than tackling poverty solely through legislation, New York City created "an innovation lab to test a diverse new generation of antipoverty programs," focusing on "the design, implementation, and evaluation of innovative programs ...."3o Among the center's strategic approaches are " $[u]$ sing data and evaluation to improve programs and allocate resources based on measurable results" and "[s]haring lessons learned and advocating on a national level for strategies shown to make a difference." ${ }^{31}$ These highly touted federal and local initiatives represent a trend in governing structures. They are most certainly ripe for criticism of both their lack of legal mechanisms to ensure that they treat individuals fairly and their lack of mechanisms to ensure democratic participation in policy creation. Nonetheless these governing structures give communities and advocates an opening through which to seize on some of the participation and evaluation methodologies to make programs more responsive to their needs.

Before embracing these structures, however, one should examine their flaws. At their heart the new governing structures rely on collaborators-the workforce investment board or New York City's Economic Opportunity Commission-to set goals, design and evaluate programs, and redesign based on the evaluation. The emphasis on broad participation and evaluation is facially attractive, but the theory assumes both a genuinely broad,

\footnotetext{
${ }^{27}$ In academic circles these trends are referred to by a variety of terms; for an extensive discussion, see the articles from a 2009 symposium, New Governance and the Transformation of Law, 2 Wisconsin Law Review (2010). See also Law And New GovernanCE IN THE EU AND THE US (Gráinne de Búrca \& Joanne Scott eds., 2006).

${ }^{28}$ Workforce Investment Act, 29 U.S.C. §§ 2801 et seq.

29/d. § 2832.

${ }^{30}$ New York City Center for Economic Opportunity, Early Achievements and Lessons Learned (Jan. 2009), http://bit.ly/fuhpsn (see Letter from Mayor Michael R. Bloomberg in front matter ("an innovation lab") and Executive Summary 1 ("the design, implementation")).

${ }^{31} / d$. at 1 .
} 
collaborative structure and equality of power among the collaborators. In poverty policy a collaborative body can easily fail to reflect the real needs of poor communities. It can simply fail to facilitate participation by poor communities, as was the case both with the program that Community Voices Heard studied and with New York City's Center for Economic Opportunity. ${ }^{32}$ The collaborative body can also co-opt poor people and treat them as tokens while giving them essentially no say, leading to similarly bad results. ${ }^{33}$

Over a long history social welfare policy has been used to subordinate communities and keep their residents available for the low-wage labor market. Unless participation mandates are substantive and shift dynamics sufficiently to give real power to communities, this history will persist. Government will simply continue to create policies and programs that appear to help poor people but actually do much more to subordinate than to support. I suggest that, rather than adopting new governing structures wholeheartedly, poor communities and their advocates capitalize on the political emphasis on participation and evaluation to create a community seat at the collaborative table. This seat could make possible a significantly more effective role for poor communities in creating and evaluating social welfare policy. What follows is one possible structure for which advocates might press. Because others could also be effective and feasible in a particular community, this proposal is meant more as food for thought than as a blueprint.

\section{Community-Based, Research-Driven Participation as a Potential Response}

Drawing on the concepts of collaboration, experimentation, and accountability at the root of new governing structures and the lessons from the work of Community Voices Heard, and mindful that successful community participation must be robust, I propose, as a means to render meaningful community participation in the governance structure, the creation of a body to monitor social service contracts. Perhaps the most important attribute of any monitoring structure is assurance that substantial participation by welfare recipients and low-income communities is part of all aspects of the body's work. Such a structure would broaden the range of participants in policy formulation and augment and build on the political power of community-based groups.

As proposed, the monitoring body would be separate and oversee all aspects of contracting for social services. It would ensure that contracting processes are transparent, that the voices and priorities of potential recipients of the service are heard, and that these constituents have the resources and structural mechanisms to influence contract terms.

The monitoring body could be created by the legislative branch of local government or by publicly elected officialscomptrollers, public advocates, and the like-whose offices engage in oversight functions. The body could receive substantial structural support from private funding sources concerned with the accountability and effectiveness of social service contracts. ${ }^{34}$ The body could be a separately staffed organization or an ongoing committee with organizational members, such as the local workforce investment boards that are mandated by the Workforce Investment Act.

Successful monitoring bodies must have, in addition to community control, two basic characteristics: (1) an altered notice and comment structure in the procurement process and (2) mandates to enable the monitoring body to design and implement an ongoing research agenda.

${ }^{32}$ For an extensive discussion of the accountability of New York City's Center for Economic Opportunity, see my Governance, Accountability and the New Poverty Agenda, 239 Wisconsin LAw Review 269 (2010).

${ }^{33}$ This often occurs in local Workforce Investment Act implementation; see my Welfare Reform, Privatization and Power: Reconfiguring Administrative Law from the Ground Up, 74 BROoKLYN LAW REVIEW 275 (2009).

${ }^{34}$ Given the current emphasis on evaluation among private funders, efforts to fund these initiatives through a combination of public and private sources may well be successful. For some examples of this focus, see Ford Foundation at http://bit.ly/ etTOau and Bill and Melinda Gates Foundation at http://bit.ly/eQcGuU. 
Regarding the first, to advance the values of government transparency and public accountability, as well as to create structures that strengthen the political clout of traditionally subordinated communities, procurement policies must be amended to invite substantial input from both the public and the monitoring body. This element is important because, as privatization has taken hold, contract terms have largely replaced regulations. In the welfare-to-work area, contracting is a closed process with little opportunity for participation by affected communities. Thus any accountability structure must incorporate into the procurement process traditional public law concepts of government transparency and opportunity for public participation. Among the changes needed are publishing proposed contract terms concerning performance measures before the terms are adopted; instituting a comment period during which the monitoring body, along with the general public, can evaluate the proposed performance measures and make recommendations; and publishing comments received from the monitoring body and the public, along with agency responses. These mechanisms would give both members of the community and the monitoring body access to terms and the chance to comment on them before their use in an executed contract.

Second, among the principles of new governing structures that are particularly attractive in this context are the emphasis on experimentation, evaluation, and flexibility to redefine programs in response to successes and failures. As every good social science researcher knows, however, the quality of any evaluation depends on the quality of the questions asked and the ability of researchers to get real answers. The role of the proposed monitoring body is, in large part, to provide ongoing evaluation that is driven by the self-articulated needs of program clients. To effectuate this agenda, the body must be able to force government actors and private entities to record and make publicly available data on outcomes that the monitoring body identifies, whether or not those outcomes are included in the contract terms. The monitoring body must also have ongoing access to program participants as well as government and private staff involved in designing and implementing the program.

Like the need for substantial control by program participants above, this research-focused proposal represents a significant departure from traditional administrative law concepts as well as from participatory governance concepts. Like the necessity for community control, this element responds to the problems of new governing structures when dealing with traditionally subordinated populations and the need to account explicitly for disproportionate power in designing contracting processes. A robust ability to force collection and publication of data is essential in lending political weight to a monitoring body.

A fundamental contradiction lies at the heart of this proposal. Perhaps the government's historic and current role in creating and implementing social welfare policy is so fundamentally intertwined with initiatives such as welfare reform and the contracts described by Community Voices Heard that reliance on government to create and monitor contracts for the provision of social services would seem inevitably to continue this history of subordination. Thus there is a certain irony in advocating the creation of monitoring bodies by and with the government. If the history is determinative, the proposal is likely to be politically unfeasible to implement or to be co-opted in a way that fundamentally undermines its strength. My belief that a better outcome is possible comes from a few observations. First, the technocratic efficiency justifications that are the public face of privatization are also its Achilles' heel. Community Voices Heard's analysis of outcomes, when framed as a matter of economic efficiency, bolsters less politically charged and highly credible assertions that funds are being wasted; the analysis may motivate other branches of government or quasi-governmental bodies to step in to improve outcomes. While that does not lead, per se, to communityled monitoring, it does offer a less overtly political opening for communities to advocate additional oversight. 
Second is the presence, in at least some communities, of community-based, membership-led groups such as Community Voices Heard. The creation of a monitoring body, even in a weaker form than proposed here, offers a point of intervention, an additional site through which organizations can assert themselves and engage in the politically contested questions of whose interests social welfare programs should serve. And, in turn, participation in such a body could raise the institutional capacity of less strongly established community-based groups that might lead to increased political power.

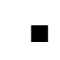

A few words about limited advocacy resources: Having spent well over a decade working on welfare issues in New York City, I am well aware of the limited resources available to advocate on behalf of welfare recipients and of the incredible necessity to continue to enforce what few procedural, substantive, constitutional, and statutory protections still apply. However, given the scale of privatization and its broad applicability to the wide range of programs traditionally run by the government, I urge that efforts to confront privatization be expanded and that others in the advocacy community join forces with community-based organizations to advocate structures that augment genuine political participation and respond directly to privatization. ${ }^{35}$

\footnotetext{
${ }^{35}$ Along with Community Voices Heard, the National Center for Law and Economic Justice works extensively on these issues in the welfare area (see National Center for Law and Economic Justice, Privatization and Modernization, http://www. nclej.org/key-issues-privatization.php).
} 


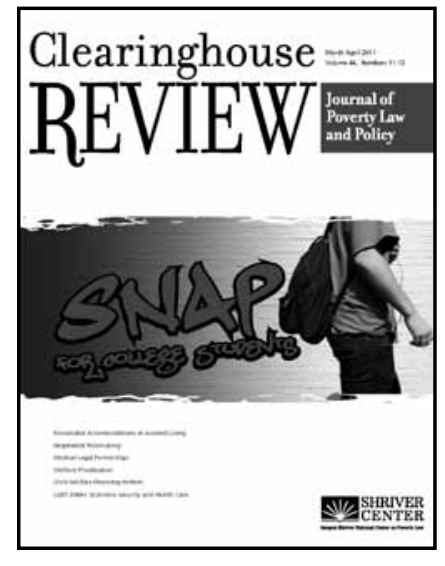

\section{Subscribe to Glearinghouse Review!}

Clearinghouse Review: Journal of Poverty Law and Policy is the advocate's premier resource for analysis of legal developments, innovative strategies, and best practices in representing low-income clients. Each issue of the REVIEw features in-depth, analytical articles, written by experts in their fields, on topics of interest to poor people's and public interest lawyers. The REVIEW covers such substantive areas as civil rights, family law, disability, domestic violence, housing, elder law, health, and welfare reform.

\section{Subscribe today!}

We offer two ways to subscribe to CLEARINGHOUSE REVIEW.

A site license package includes printed copies of each monthly issue of Clearinghouse ReVIEW and online access to our archive of articles published since 1967. With a site license your organization's entire staff will enjoy fully searchable access to a wealth of poverty law resources, without having to remember a username or password.

Annual site license package prices vary with your organization size and number of printed copies.

Legal Services Corporation-funded programs: \$170 and up

Nonprofit organizations: $\$ 250$ and up

Law school libraries: $\$ 500$
A print subscription includes one copy of each of six issues, published bimonthly. Annual rates for the print-only subscription package are as follows:

Legal Services Corporation-funded programs: $\$ 105$

Nonprofit organizations: $\$ 250$

Individuals: $\$ 400$

A print subscription for Legal Services Corporation-funded programs and nonprofit organizations does not include access to the online archive at www.povertylaw.org.

Please fill out the following form to receive more information about subscribing to CLEARINGHOUSE REVIEW.

Name

Organization

Street address Floor, suite, or unit

City State Zip

E-mail

My organization is

$\square$ Funded by the Legal Services Corporation

$\square$ A nonprofit

$\square$ A law school library

$\square$ None of the above
What is the size of your organization?

$\square$ 100+ staff members

51-99 staff members

$\square$ 26-50 staff members

$\square$ 1-25 staff members

$\square$ Not applicable

Please e-mail this form to subscriptions@povertylaw.org.

Or fax this form to Ilze Hirsh at 312.263.3846.

Sargent Shriver National Center on Poverty Law

50 E. Washington St. Suite 500

Chicago, IL 60602 